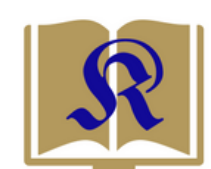

KURIOS

\title{
Memahami Konstruksi Teologi Keindahan
}

\author{
Paulus Eko Kristianto \\ Sekolah Tinggi Filsafat Driyakara, Jakarta \\ paulusekokristianto12@gmail.com
}

\begin{abstract}
True beauty brings our joy in knowing and loving everything. God is perfect, while humans are limited. True love and joy breeds love for everything as they are. True happiness is always related to our true knowledge and love of true beauty and goodness. Based on this condition, this article tries to trace the source of that true beauty to God. The conceptual frame offered in this article is looking at God in the theology of beauty. This frame is obtained through library research methods on various relevant books and journals. This study concludes that if we do not love God as God exists or loves anything above all things, we do not have true joy in loving God.
\end{abstract}

Article History

Submit:

16 April 2019

Revised:

11 Mei 2019

Accepted:

26 Oktober 2019

Keywords

(kata kunci):

beauty

of God;

joy;

love;

theology of

beauty;

Allah;

kasih;

keindahan;

teologi

keindahan;

kegembiraan Penelitian ini memperoleh kesimpulan bahwa jika kita tidak mencintai Allah sebagaimana Allah ada atau mencintai apapun di atas segala sesuatu, kita tidak memiliki kegembiraan sejati dalam mencintai Allah.

\section{Pendahuluan}

Keindahan merupakan misteri yang memikat dan mempesonakan. Keindahan melahirkan sukacita dan damai. Hal ini dirasakan tanpa bantuan dari berbagai konsep dan penjelasannya. Hakikat keindahan ialah suatu kegembiraan selama-lamanya dalam penglihatan yang membahagiakan. Keindahan memiliki kekuatan gaib yang memikat dan mengundang siapapun. Armand E. Maurer menunjukkan orang Yunani dapat mengenali kekuatan gaib ini ketika menyebut "to kalon" nama yang indah, dari kata kerja kaleo, yang berarti memanggil 
atau menarik perhatian. ${ }^{1}$ Dengan kata lain, keindahan merupakan daya tarik sesuatu yang baik dan menggerakkan sehingga menarik kita untuk membangun kesetiaan, komitmen, dan prestasi. Daya tarik terhadap prestasi dan keunggulan manusia membangkitkan sikap kekaguman atau penghargaan menakjubkan yang disertai oleh kepuasan dan kegembiraan. Keindahan merupakan kekuatan kebaikan yang menguasai, memfokuskan, dan menopang perhatian yang memang dibutuhkan agar kita menjadi cerdas, berpikiran sehat, bertanggungjawab, dan mencintai. ${ }^{2}$ Cinta sejati, persahabatan, komitmen, dan komunitas berhubungan dengan keindahan.

Pada komentarnya di buku Divine Names dari Pseudo Dionysius, Thomas Aquinas menegaskan keindahan merupakan motivasi utama penciptaan. ${ }^{3}$ Allah ingin mengomunikasikan keindahan ke semua ciptaannya. Bahkan, Allah juga telah memberikan eksistensi kepada segala sesuatu, menggerakkan, dan memeliharanya. Keindahan turut mengambil wujud yang kelihatan ketika Sabda Allah menjadi manusia dan tinggal di antara kita. Thomas Aquinas menggambarkan bahwa Kristus memiliki keindahan karena Ia ikut serta dalam kodrat Ilahi. ${ }^{4}$ Hal ini selaras dengan ungkapan Paulus bahwa Kristus ada dalam rupa Allah (Filipi 2: 6) dan dalam Dialah berdiam secara jasmaniah seluruh kepenuhan keAllahan (Kolose 2: 9). Aquinas juga menambahkan bahwa Kristus memiliki keindahan dalam keutamaan moral, khususnya keadilan dan kebenaran. ${ }^{5}$ Kristus memiliki keanggunan kelakuan moral yang jujur dan bijaksana. Berbagai gambaran tersebut dikemas John Navone dalam bingkai teologi keindahan. Teologi keindahan merupakan bentuk refleksi teologis tentang keindahan itu sendiri terhadap Allah, manusia, dan alam semesta. Namun, artikel ini memfokuskan diri pada Allah.

Navone mengenalkan teologi keindahan yang menghasilkan berbagai pengandaian tertentu. Pengandaian ini di antaranya Allah hadir di mana pun Ia bertindak, dan di mana pun Allah bertindak, segala sesuatu menjadi ada. Allah bertindak dengan menciptakan, memelihara, dan membawa kesempurnaan segala sesuatu sehingga segala sesuatu menjadi baik, benar, dan indah. Allah dikenal dalam karya Ilahi-Nya sebagai Pencipta, Pemelihara, Penyempurna, dan Pemenuh segala sesuatu yang dapat diketahui, yang dapat dicintai, dan segala sesuatu yang menyenangkan. ${ }^{6}$ Tidak ada satu ciptaan pun dapat dikenal, dicintai, dan disenangi sungguh-sungguh lepas dari Allah. Pengetahuan, cinta, dan kesenangan Allah terhadap ciptaan bukan merupakan tanggapan Allah terhadap ciptaan, melainkan justru mereka ada karena Allah mengetahui, mencintai, dan berkenan pada diri-Nya. Dengan kata lain, pengetahuan, cinta, dan kesenangan Allah dinyatakan secara tidak langsung dalam semua ciptaan sehingga semua itu dapat diketahui, dicintai, dan disenangi.

Berangkat dari uraian tersebut, penulis mengajukan pertanyaan berikut. Bagaimana ide dasar teologi keindahan? Bagaimana desain teologi keindahan? Mengapa dan bagaimana

${ }^{1}$ Armand E. Maurer. About Beauty. (Houston: Center for Thomistic Studies, University of St. Thomas, 1983), hlm. 105.

2 John Navone. Toward A Theology of Beauty terj. Willem Daia. (Yogyakarta: Kanisius, 2007), hlm. 34.

${ }^{3}$ John Navone. Toward A Theology of Beauty, hlm. 36.

${ }^{4}$ John Navone. Toward A Theology of Beauty, hlm. 37.

${ }^{5}$ John Navone. Toward A Theology of Beauty, hlm. 37.

${ }^{6}$ John Navone. Toward A Theology of Beauty, hlm. 38. 
Allah menjadi bagian dari kajian teologi keindahan? Berbagai pertanyaan ini dapat dipandang penting guna menunjukkan bahasan memandang Allah dalam teologi keindahan. Memandang Allah dalam teologi keindahan dapat dimaknai bahwa kita dapat berefleksi tentang Allah dalam ruang teologi keindahan, atau dengan kata lain, teologi keindahan dapat mengantar kita untuk berefleksi tentang Allah. Pemahaman ini yang coba dikenalkan oleh Navone melalui pengandaian-pengandaiannya dalam berteologi keindahan.

\section{Metodologi}

Guna menjawab rumusan masalah sebagai panduan artikel ini, penulis mencoba menggunakan metode penelitian studi pustaka terhadap berbagai buku dan jurnal yang terkait teologi keindahan. Bahan pustaka tersebut kemudian diolah, direfleksikan, dan ditulis dengan menggunakan metode penulisan deskripsi analisis. Penulis menuliskan apa yang sudah direfleksikan dari berbagai bahan secara deskriptif. Kemudian, berbagai pemikiran teologi keindahan tersebut dianalisa dan ditemukan hal baru yang dapat dikembangkan berikutnya.

\section{Pembahasan}

\section{Ide Dasar Teologi Keindahan}

Keindahan merupakan bagian utama dari kehidupan beragama selama beberapa periode sejarah gereja. Pada abad pertengahan, keindahan dipakai untuk menjelaskan iman. Para teolog Kristen telah menulis kajian keindahan, tetapi kuantitasnya masih minim. Namun bila diklasifikasikan, teolog Reformasi, Roman Katolik, dan Ortodoks Timur lebih banyak membahas teologi keindahan dibanding teolog Protestan. ${ }^{7}$ David Bentley Hart menegaskan keindahan memang lebih mudah dinikmati setelah kita mendengar puisi dan musik, ketimbang sesuatu yang tidak tersentuh (invisible) dan imajiner. ${ }^{8}$ Herman Bavinck tidak sependapat dengan Hart. Bagi Bavinck, keindahan terletak di antara konten (content) dan bentuk (form), ide (idea) dan penampilan (appearance), kesatuan dalam keberagaman, kemegahan (splendor), kemuliaan (glory), kesempurnaan bercahaya (radiant perfection). ${ }^{9}$ Oleh karenanya, Bavinck menilai kita tetap bisa merasakan keindahan.

Sebagai fondasi dasar, keindahan merupakan komunikasi. Kita harus hati-hati menganalisis ekspresi artistik untuk mengetahui obyek penyerahan diri kita. Persatuan (unity), keberagaman (diversity), proporsi (proportion), dan kemegahan (splendor) mendeskripsikan obyek keindahan. Namun, seni (art) dan keindahan (beauty) sering dianggap sama. Dalam kajian teologi keindahan, seni dan keindahan sedikit dibedakan sebagai berikut. ${ }^{10}$

\footnotetext{
${ }^{7}$ Armand E. Maurer. About Beauty, hlm. 67.

8 David Bentley Hart. The Beauty of the Infinite: The Aesthetics of Christian Truth. (Grand Rapids: Eerdmans, 2003), hlm. 17.

9 Jeremy Begbie. Voicing Creation's Praise: Towards a Theology of the Arts. (Edinburgh: T \& T Clark, 1991), hlm. 99.

${ }^{10}$ Steve Turner. Imagine: A Vision for Christians in the Arts. (Downers Grove: InterVarsity Press, 2001), hlm. 45 .
} 


\begin{tabular}{|l|l|}
\hline \multicolumn{1}{|c|}{ Seni } & \multicolumn{1}{c|}{ Keindahan } \\
\hline Allah sebagai sumber seni & Allah sebagai sumber keindahan \\
\hline $\begin{array}{l}\text { Proses penciptaan merefleksikan seni dan } \\
\text { kreativitas Allah }\end{array}$ & $\begin{array}{l}\text { Proses penciptaan merefleksikan keindahan } \\
\text { tindakan-tindakan kreativitas Allah }\end{array}$ \\
\hline $\begin{array}{l}\text { Ciptaan Allah yang paling artistik adalah } \\
\text { manusia. Manusia dibuat dengan penuh } \\
\text { ketakutan dan luar biasa (Mazmur 139: } 14) .\end{array}$ & $\begin{array}{l}\text { Ciptaan Allah yang paling indah adalah } \\
\text { manusia (Kejadian 1: 27-31). }\end{array}$ \\
\hline $\begin{array}{l}\text { Manusia diciptakan untuk merefleksikan } \\
\text { kualitas artistik Allah (Keluaran 26:1) }\end{array}$ & $\begin{array}{l}\text { Manusia diciptakan untuk merefleksikan } \\
\text { keindahan Allah (Kejadian 1: 27) }\end{array}$ \\
\hline $\begin{array}{l}\text { Manusia dibuat menurut gambar Allah. } \\
\text { Manusia itu kreatif. }\end{array}$ & $\begin{array}{l}\text { Manusia dibuat menurut gambar Allah. } \\
\text { Manusia dapat menghargai keindahan }\end{array}$ \\
\hline $\begin{array}{l}\text { Orang yang dilahirkan kembali } \\
\text { bertanggungjawab untuk menggunakan } \\
\text { kemampuan artistiknya untuk kemuliaan }\end{array}$ & $\begin{array}{l}\text { Orang yang dilahirkan kembali } \\
\text { bertanggungjawab untuk merefleksikan } \\
\text { keindahan Allah dan ciptaan-Nya. }\end{array}$ \\
\hline $\begin{array}{l}\text { Allah dan gambar-Nya seumpama variasi } \\
\text { dalam menciptakan dan menampilkan seni. }\end{array}$ & $\begin{array}{l}\text { Allah dan gambar-Nya menikmati variasi } \\
\text { dalam menghargai keindahan. }\end{array}$ \\
\hline $\begin{array}{l}\text { Allah tertarik pada detail karya artistik yang } \\
\text { dilakukan umat-Nya. }\end{array}$ & $\begin{array}{l}\text { Allah tertarik pada keindahan produk akhir } \\
\text { dari karya kreatif umat-Nya. }\end{array}$ \\
\hline $\begin{array}{l}\text { Allah memberi manusia berbagai kemampuan } \\
\text { artistik untuk mencerminkan kemuliaan-Nya. }\end{array}$ & $\begin{array}{l}\text { Allah memberi manusia kemampuan untuk } \\
\text { memantulkan kecantikannya dan keindahan } \\
\text { ciptaan-Nya melalui berbagai karunia spiritual. }\end{array}$ \\
\hline $\begin{array}{l}\text { Allah memperingatkan kita dan tidak } \\
\text { membiarkan apa pun yang diciptakan oleh } \\
\text { manusia menjadi obyek ibadah. }\end{array}$ & $\begin{array}{l}\text { Allah memperingatkan manusia untuk tidak } \\
\text { menyembah keindahan umat manusia, ciptaan, } \\
\text { karya manusia, atau menjadi sombong dalam } \\
\text { apa yang diciptakan seseorang. }\end{array}$ \\
\hline $\begin{array}{l}\text { Kerajaan Allah dipenuhi oleh karya dan seni- } \\
\text { Nya. }\end{array}$ & $\begin{array}{l}\text { Kerajaan Allah terlihat terlampau indah } \\
\text { sehingga menyulitkan bahasa manusia untuk } \\
\text { menggambarkannya. }\end{array}$ \\
\hline Melalui Kritus, seni telah ditebus. & Melalui Kristus, keindahan telah ditebus. \\
\hline
\end{tabular}

Dalam teologi keindahan, seni dan keindahan bersifat aktif. Dengan jelas dan konsisten, Alkitab melihat keindahan seumpama kebenaran (truth) dan kebaikan (goodness) yang memiliki kualitas obyektif. $^{11}$ Yesaya 28: 1-6 merupakan bagian eksplisit yang menunjukkannya. Suku Efraim dibandingkan dengan pemabuk. Mahkota kebanggaan Efraim merupakan ibukotanya. Namun pada ayat 1 dan 4, kita menemukan mahkota tersebut dijelaskan bagai bunga yang memudar dari keindahannya yang mulia. Dalam bahasa Ibrani, kata "kabod" (kemuliaan) berangkat dari kata dasar yang berarti berat (weight) atau penting (importance). Kata ini digunakan untuk menerangkan kemuliaan Tuhan, khususnya mengindikasikan manifestasi Allah. Yesaya 28: 5 menunjukkan bahwa kemuliaan (glory) bersinonim dengan keindahan (beauty). Kemuliaan Allah merupakan bagian dari Allah sendiri. Hubungan antara kemuliaan Allah dan keindahan sebagaimana diterangkan dalam Perjanjian Lama semakin terekspresi secara penuh melalui kehadiran Yesus Kristus (Yohanes 1: 14). Hans Urs von Balthasar menegaskan bahwa Yesus merupakan kanon (standar) absolut bagi semua keindahan yang ada. ${ }^{12}$ Kanon tersebut tidak dimaksudkan bahwa manifestasi

${ }^{11}$ David Bentley Hart. The Beauty of the Infinite, hlm. 78.

${ }^{12}$ Hans Urs von Balthasar. The Glory of the Lord: A Theological Aesthetics III: Studies in Theological Styles. (San Francisco: Ignatius, 1982), hlm. 247. 
Allah yang terlihat dari kemuliaan-Nya memberi kita deskripsi rinci dari setiap kemungkinan pemandangan, aroma, atau suara yang dapat digambarkan sebagai bagian keindahan.

Dalam teologi keindahan, keindahan itu bersifat aktif dengan berbicara (Mazmur 19), mengundang (Mazmur 27), memelihara (Galatia 5: 22), menyamankan (2 Samuel 16: 14-23), dan menghargai (Amsal 4: 9). ${ }^{13}$ Namun, mereka juga dapat menjadi penyebab berbagai kesombongan dan penipuan (Amsal 31: 30; Yehezkiel 27: 3). Keindahan adalah salah satu tema yang dibahas mulai dari Kejadian 1 - Wahyu 22. Dalam Kejadian 1, Allah melihat segenap ciptaan dan mengatakan bahwa semua itu baik dan indah. Keluaran 28: 2 dan 31: 111 menunjukkan Tuhan memerintahkan pengrajin untuk membuat barang-barang indah di mana umatnya akan melihat kemuliaan dan keindahannya.

Yohanes menunjukkan Kerajaan Allah mendemonstrasikan keindahan dan artistik kerja Allah (Wahyu 21-22). ${ }^{14}$ Deskripsi tersebut menunjukkan bahwa Allah menjadikan segala sesuatu baru (21: 5), keindahan kota yang kudus (21: 2, 11-22), kota yang penuh dengan kemuliaan Allah dan cahayanya sama seperti permata yang paling indah, bagaikan permata yaspis, jernih seperti kristal, dan temboknya besar lagi tinggi dan pintu gerbangnya dua belas buah malaikat, dan di atasnya tertulis nama kedua belas suku Israel (21: 11-12). Seluruh keindahan Trinitas terpancar dan teriluminasi ke kota yang abadi (21: 11-25). Kota yang abadi memiliki sungai kehidupan yang indah dan menghasilkan buah kenikmatan (22: 1-2).

\section{Desain Bahasan Teologi Keindahan}

Dari sisi filsafat, Pythagoras, Plato, dan Plotinus menggambarkan keindahan sebagai kesemarakan abadi dari Yang Esa yang tampak melalui Yang Banyak. ${ }^{15}$ Hal ini berarti dalam banyak bentuk yang berbeda-beda dalam alam semesta kita, Yang Esa memancarkan dan memberikan kesemarakan dan makna kepada semua realitas. Aristoteles memahami keindahan dengan menggunakan istilah harmoni. Harmoni di sini bermakna suatu keadaan tatkala segala sesuatunya selaras. Selain itu, harmoni juga dimaknai suatu keadaan tatkala, dalam suatu teori ilmu pengetahuan atau Parthenon, orang memiliki keyakinan bahwa tidak sesuatu pun dapat ditambah atau dikurangi. Dengan kata lain, semua bagian berada dalam keharmonisan dengan semua bagian yang lain.

Ketika memikirkan triade atau tritunggal keindahan, kebenaran, dan kebaikan, Plato telah memberi tempat pertama pada keindahan. Hal itu dikarenakan adanya keyakinan bahwa keindahan itu harmoni. Namun, Plato juga menegaskan kebaikan etis yang terdiri dari cara bertindak tertentu telah membawa keharmonisan dengan manusia lain. Oleh karenanya, kata pada bahasa Yunani yang menunjuk keindahan dan kebaikan itu sama yaitu kalon. ${ }^{16}$ Selain keharmonisan, Navone menunjukkan keindahan juga bertindak mencipta, mempertahankan, dan menarik menuju kesempurnaan seluruh ciptaan. ${ }^{17}$ Pada prosesnya, semua keindahan yang diciptakan telah memantulkan dan mengambil bagian dalam kesemarakan hakikat keindahan.

\footnotetext{
${ }^{13}$ Francis A. Schaeffer. Art and The Bible. (Downer Grove: InterVarsity Press, 1973), hlm. 34.

${ }^{14}$ Francis A. Schaeffer. Art and The Bible, hlm. 34.

${ }^{15}$ John Navone. Toward A Theology of Beauty, hlm. ix.

${ }^{16}$ John Navone. Toward A Theology of Beauty, hlm. x.

${ }^{17}$ John Navone. Toward A Theology of Beauty, hlm. x.
} 
Poin pemikiran ini yang coba ditangkap dan dikaji para teolog melalui desain teologi keindahan.

Dalam teologi keindahan, Yesus Kristus selaku hakikat dasar keindahan telah menjelmakan, mengilhami dan melatarbelakangi teologi keindahan. Pengandaian yang dipegang para teolog keindahan yaitu jika Allah adalah hakikat kebahagiaan, maka persekutuan dengan Allah menjadi persekutuan dengan hakikat kebahagiaan. Kemudian, jika hakikat kebahagiaan selalu mengetahui kebenaran-Nya dan mencintai kebaikan-Nya serta berkenan pada keindahan-Nya, maka kebahagiaan akhir dan abadi ditinjau dari segi karunia penglihatan yang membahagiakan. Semua tak lain merupakan bagian persekutuan hakikat kebahagiaan yakni mengetahui kebenaran-Nya, mencintai kebaikan-Nya, dan berkenan pada keindahan-Nya. ${ }^{18}$

Dalam bukunya The Glory of the Lord: A Theological Aesthetic, Balthasar merumuskan bahwa pengembangan teologi Kristen perlu diperlengkapi dengan visi yang benar dan baik dengan keindahan. ${ }^{19}$ Tuhan menentukan standar kebenaran (truth) sebagaimana yang Dia lakukan untuk kebaikan (goodness) dan keindahan (beauty). Ketiga nilai ini bukan bagian terpisah. Kebenaran didefinisikan dengan keberadaan (being). Kebaikan (goodness) didefinisikan dengan kebenaran (truth). Keindahan (beauty) didefinisikan dengan kebaikan (goodness) secara obyektif demikian dan bukan keinginan (desire), kesenangan (pleasure), perasaan (feeling), imajinasi (imagination).

Balthasar berpendapat Tuhan membuat standar kebenaran (truth) sama halnya dengan kebaikan (goodness) dan keindahan (beauty). ${ }^{20}$ Orang Kristen mungkin menolak standar tersebut. Bila kita melakukannya, kita sedang menempatkan diri kita sendiri pada posisi kaum Samaritan yang mengabaikan nubuat Yesaya. Kita membuat diri kita siap untuk memetik, dan bersedia untuk dibanjiri oleh budaya yang menegaskan bahwa kecantikan ada di mata yang melihatnya. Maka, kebaikan (goodness) dipandang berdasarkan situasi tertentu dan kebenaran (truth) didefinisikan dan bahkan dapat didefinisikan ulang oleh siapapun.

Karl Barth tidak mengatakan bahwa Allah itu indah pada perspektif manusia ketika melihatnya. Baginya, Allah merupakan basis dan standar segala sesuatu untuk mengukur keindahan dan tumpuan keseluruhan keindahan. ${ }^{21}$ Pada desain teologi keindahan, Jeremy Begbie mengembangkan gagasan Barth bahwa teologi keindahan banyak membahasnya pada beberapa dekade mendatang. ${ }^{22}$ Keindahan dimungkinkan dapat disalahpahami dan disalahgunakan. Tindakan ini diharapkan tidak menghalangi kita dari upaya pemaknaan keindahan Allah. Memaknai keindahan Allah melalui kontemplasi dilakukan dengan kesadaran supaya kita serupa dengan-Nya. Hal ini berarti kita menjadi indah sesuai dengan rahmat dan panggilan dari kehendak, cinta, dan kebenaran Allah bagi kita. Segala upaya memuliakan kehendak sendiri tentu dapat merusak bentuk keindahan kita yang telah diberikan Allah.

\footnotetext{
${ }^{18}$ John Navone. Toward A Theology of Beauty, hlm. x.

${ }^{19}$ Hans Urs von Balthasar. The Glory of the Lord, hlm. 9.

${ }^{20}$ Hans Urs von Balthasar. The Glory of the Lord, hlm. 9.

${ }^{21}$ Karl Barth. Church Dogmatics. (Edinburgh: T \& T Clark, 1970), hlm. 650.

22 Jeremy Begbie. Beholding the Glory: Incarnation through the Arts. (Grand Rapids: Baker, 2000), hlm.
} xiii. 
Kita perlu menyadari bahwa sebagaimana ada perbedaan antara yang baik sungguhsungguh dan yang tampaknya baik, demikian pula ada perbedaan antara yang indah sungguhsungguh dan yang tampaknya indah menggiurkan. Keindahan sejati dapat menarik kita ke pemenuhan dan kebahagiaan kita yang sejati, tetapi keindahan semu dapat mendatangkan apa saja yang memikat kita pada penghancuran diri, baik secara moral, maupun spiritual. Keindahan sejati mendatangkan kegembiraan kita untuk mengetahui dan mencintai segala sesuatu sebagaimana mereka ada. Kebahagiaan sejati senantiasa berhubungan dengan pengetahuan dan cinta kita yang sejati terhadap keindahan dan kebaikan sejati. Namun, penipuan diri tidak pernah dapat menjadi dasar kegembiraan atau kebahagiaan.

\section{Memahami Allah dalam Teologi Keindahan}

Alkitab menunjukkan bagaimana Allah diekspresikan dengan berbagai konsep keindahan di antaranya keindahan (beauty), keunggulan (excellency), kejayaan (glory), kehormatan (honor), dan keagungan (majesty). ${ }^{23}$ Konsep tersebut melekat pada karakter-Nya. Hakikat keindahan menyatakan dan mengomunikasikan diri Yesus kepada semua manusia melalui kemuliaan, rahmat, kebenaran, dan kegembiraan. ${ }^{24}$ Allah Bapa telah memberi kita Yesus Kristus sehingga kita diizinkan ikut serta dalam kegembiraan abadi Allah Tritunggal dalam suatu kehidupan yang dikuasai kebenaran, kebaikan, dan keindahan. Pengorbanan Yesus di kayu salib telah menyinarkan keindahan tertinggi dari Allah. Kemuliaan Allah dikenal ke mana pun. Upaya itu membuat sukacita Allah menjadi bagian kita. Keindahan mengubah rupa dunia pada cinta pemberian diri Kristus yang disalibkan dan dimuliakan. Sebab, keindahan Allah itu menarik, memikat, mengubah, dan menyenangkan kita.

Allah adalah sumber dan dasar kemuliaan dan keindahan sejati (Mazmur 62: 6, 8). Ketika iblis mencobai Yesus dengan berbagai tawaran yang menggiurkan, Yesus melawannya dengan ajakan menyembah Tuhan (Matius 4: 8-10). Pengalaman ini menegaskan bahwa keindahan semu sebagaimana ditawarkan iblis telah menjadi daya tarik atau pikat dari kebaikan yang nampaknya baik justru dapat merusak keunggulan manusia dengan segala kegembiraan dan kebahagiaan. Navone menunjukkan bahwa Yohanes berbicara tentang empat bentuk cinta yang menjauhkan kita dari kemuliaan atau keindahan Allah yaitu (1) kita melawan dan menolak Allah karena kita mencintai kegelapan (Yohanes 3:19); (2) kita mencintai kehormatan manusia (Yohanes 12:43); (3) kita mencintai hidup kita sendiri (Yohanes 12:25); dan (4) kita mencintai dunia (1 Yohanes 2: 15). ${ }^{25}$ Dari pemahaman tersebut, kita dapat melihat bahwa tiga cinta pertama merupakan cinta diri yang tidak teratur dan cinta diri yang lepas dari ketergantungan pada Allah, sedangkan cinta yang keempat berarti cinta kekuasaan yang melawan dan bertentangan dengan pemberian diri Allah.

Penolakan terhadap keindahan Allah dimotivasi oleh cinta akan dunia tanpa Allah. Kehidupan tanpa Allah sama halnya tinggal dalam kegelapan (Yohanes 12:46). Kegelapan merupakan keadaan kesadaran manusia yang diakibatkan oleh kecintaan manusia terhadap pekerjaan-pekerjaan yang dilakukan dan bersifat berlawanan dengan Allah. Bila kita mencari

${ }^{23}$ Philip Graham Ryken. Art for God's Sake: A Call to Recover the Arts. (New Jearsey: P \& R Publishing, 2006), hlm. 36.

${ }^{24}$ John Navone. Toward A Theology of Beauty, hlm. 41.

${ }^{25}$ John Navone. Toward A Theology of Beauty, hlm. 45. 
hormat bagi diri sendiri, maka kita tidak dapat tinggal dalam keindahan Allah (Yohanes 7: 18; 8:50). Hal itu dikarenakan kita melepaskan semua hasrat untuk keindahan sejati yang berasal dari Allah. Dengan kata lain, cinta terhadap diri sendiri dan apa yang kita miliki di dunia ini dapat mengalahkan cinta kita akan Kristus. Menyambut keindahan Allah berarti kita mencoba cinta kepada kemuliaan Allah (Yohanes 12: 43), cinta kepada terang (Yohanes 3:19), cinta kepada Kristus (Yohanes 8: 42-47), dan cinta kepada Allah (Yohanes 5: 42; 1 Yohanes 2: 15). ${ }^{26}$ Barangsiapa mencintai Yesus Kristus, dia mencintai Bapa. Siapa yang mencintai kemuliaan Allah yang nyata dalam Yesus, ia memiliki cinta Allah dalam dirinya dan akan diubahkan oleh cinta itu. Di sisi lain, siapapun yang mencintai dirinya sendiri akan terpisah dari keindahan sejati. Melalui kedatangan Yesus, kita terbebas, meninggalkan kegelapan, dan datang pada terang (Yohanes 12:35). Penolakan kita mewakili suatu keputusan untuk tinggal tetap dalam keadaan tanpa Kristus.

Berjalan dalam kegelapan berarti hidup dan bertindak dalam keadaan terpisah dari Allah (Yohanes 8:12; 12:35; 1 Yohanes 1:6). Dalam hal ini, kegelapan merupakan keadaan kesadaran manusia yang diakibatkan oleh kecintaan manusia terhadap pekerjaan-pekerjaan yang dilakukan berlawanan dengan Allah. Kegelapan juga dimaknai mereka yang mencari hormat bagi dirinya atau mengagungkan dirinya (Yohanes $7: 18 ; 8: 50$ ) tidak dapat tinggal di dalam iman akan Yesus karena mereka mencari kemuliaan dan kepentingan manusia. Cinta terhadap diri sendiri dan terhadap apa yang kita miliki di dunia ini yang mengatasi cinta kita akan Kristus membawa akibat bahwa kita kehilangan hidup atau cinta yang kekal. Kristus mengutuk cinta diri dengan mengacu pada diri-Nya sendiri (Yohanes 12: 25).

Yohanes menghubungkan keempat cinta dengan iman Kristen. Cinta tersebut menunjuk pada cinta kepada kemuliaan Allah (Yohanes 12:43), cinta kepada terang (Yohanes 3: 19), cinta kepada Kristus (Yohanes 8: 42-47), dan cinta kepada Allah (Yohanes 5: 42; 1 Yohanes 2: 15). ${ }^{27}$ Barang siapa mencintai Yesus Kristus, dia mencintai Bapa. Siapa yang mencintai kemuliaan Allah yang nyata dalam Yesus Kristus, dia memiliki cinta Allah dalam dirinya dan akan diubah oleh cinta itu. Barangsiapa mencintai Yesus Kristus, dia mencintai Bapa. Siapa yang mencintai kemuliaan Allah yang nyata dalam Yesus, dia memiliki cinta Allah dalam dirinya dan akan diubah oleh cinta itu. Sementara itu, siapa pun yang mencintai dirinya sendiri di atas segalanya telah membuat mereka terpisah dari Allah.

Yohanes juga menggambarkan Yesus sebagai gembala yang baik (Yohanes 10:11). Hal itu digambarkan melalui penggunaan kata "kalos". Kalos berarti sehat secara organik, pantas atau baik, berguna, dapat dipergunakan, dan indah dalam arti memberi kesan sensual, senang, menarik, dan cantik. ${ }^{28}$ Yesus digambarkan tidak hanya memenuhi ide gembala yang benar, melainkan kecantikan gembala sejati yang memikat. Yang baik di sini bukan hanya secara tersembunyi (agathos), melainkan juga baik sebagaimana dilihat (kalos). Keindahan melalui kebaikan-Nya dilihat sebagai tindakan yang sangat baik. Lewat tindakan itu, Ia akan menarik umat sekaligus pembuktian tindakan penyelamatan Yesus. Yesus datang bukan untuk menghakimi dunia, melainkan menyelamatkannya (Yohanes 3: 17). Bahkan, Yesus datang

\footnotetext{
${ }^{26}$ John Navone. Toward A Theology of Beauty, hlm. 47.

${ }^{27}$ John Navone. Toward A Theology of Beauty, hlm. 47.

${ }^{28}$ John Navone. Toward A Theology of Beauty, hlm. 50.
} 
supaya kita memiliki hidup dan mempunyai keselamatan dalam segala kelimpahan (Yohanes 10: 10).

Keindahan Allah mengubah rupa dunia dengan kegembiraan. ${ }^{29}$ Keindahan dunia yang telah diubah menuntut terang batin dari siapa pun yang mau mengkontemplasikannya. Orang perlu datang pada terang yang adalah Allah sendiri (Yohanes 1:9; 8:12). Allah menerangi pikiran kita untuk melihat dan mengilhami hati dengan seluruh keindahan Ilahi. Hans Urs von Balthasar telah menunjukkan bahwa pemahaman tentang kemuliaan Allah telah mengilhami orang-orang Kristen yang mencari hakikat keindahan. ${ }^{30}$ Balthasar melihat sejarah teologi Kristen sebagai suatu sejarah telah mencoba mengungkapkan kemuliaan Allah pada model dan teori tentang keindahan secara silih berganti. ${ }^{31}$ Sejak Gregorius dari Nazianze dan Boethius sampai pada Thomas Aquinas, puisi mengungkapkan keindahan yang tidak dapat dipisahkan dari gambaran tentang yang Ilahi. ${ }^{32}$ Bahkan, Yohanes dari Salib menggambarkan keindahan Allah melalui Kidung Rohani yang mengatakan, "Mari kita bergembira,

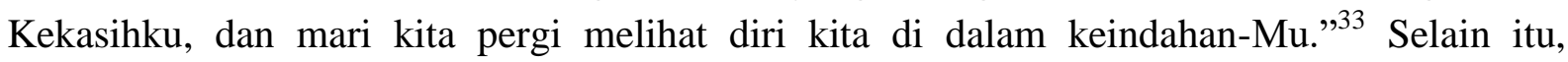
Nicholas dari Causa menganjurkan untuk memusatkan perhatian pada gambar wajah kudus Yesus sebagai langkah awal menuju kontemplasi Kristen. Dalam gereja Ortodoks, suatu teologi nonverbal yang mengungkapkan, mengajarkan, dan mencecap cita rasa keindahan Allah melalui gambar-gambar telah memperoleh pengakuan resmi, contohnya, seni gotik dan arsitektur barat telah disuguhkan secara teologis oleh Suger (tahun 1081-1151), pendiri gereja Gotik pertama dan kepala biara St. Denys sebagai bagian dari karya para mistikus dan teolog agung, di antaranya St. Victor, Hugh (1096-1140) dan Richard (1104-1173). ${ }^{34}$

Pada umumnya, para teolog menghubungkan keindahan dengan penglihatan dan pendengaran. Gagasan itu tidak ada salahnya. Bahkan, Kitab Yehezkiel pun menggambarkan keindahan dengan penglihatan di Bait Allah (Yehezkiel 40-43). Kitab Wahyu juga menunjukkannya melalui tembok-tembok Yerusalem (Wahyu 21: 10-23). Dengan kata lain, arsitektur, pewarnaan, barang-barang seni pahat atau ukir, dan musik gereja mengisyaratkan adanya hubungan penglihatan dan pendengaran dalam pendekatan komunitas-komunitas Kristen terhadap keindahan Ilahi. ${ }^{35}$ Keberadaan, bentuk, dan tindakan yang ada menjadi komponen dan dasar dari keindahan itu. Bentuk memberi jenis sinarnya kepada yang ada, baik sinar jasmani, maupun yang dapat dimengerti atau bersifat rohani. Sinar yang ada menjadi integral dengan keindahannya karena sinar menerangi budi, imajinasi, pikiran, dan dapat menyenangkan kita. ${ }^{36}$

Selain sinar, keharmonisan merupakan dasariah bagi keindahan. Hal ini biasa digambarkan kata memiliki keindahannya ketika disusun pada suatu tatanan kalimat sehingga memampukan terang budi bersinar melalui kata-kata tersebut. Sama halnya dengan musik, ketika nada disusun dengan baik, maka kita akan mendengarnya secara harmonis dan

\footnotetext{
${ }^{29}$ John Navone. Toward A Theology of Beauty, hlm. 73.

${ }^{30}$ John Navone. Toward A Theology of Beauty, hlm. 78.

${ }^{31}$ John Navone. Toward A Theology of Beauty, hlm. 78.

32 John Navone. Toward A Theology of Beauty, hlm. 78.

${ }^{33}$ John Navone. Toward A Theology of Beauty, hlm. 78.

${ }^{34}$ John Navone. Toward A Theology of Beauty, hlm. 79.

${ }^{35}$ John Navone. Toward A Theology of Beauty, hlm. 80.

${ }^{36}$ John Navone. Toward A Theology of Beauty, hlm. 80.
} 
menyenangkan bagi telinga. Navone menunjukkan bahwa hal ini juga terjadi pada berbagai tindakan manusia yang memiliki keindahan rohani karena tindakan-tindakan manusia diatur dengan baik melalui terang budi. ${ }^{37}$ Selain sinar dan penyeimbangan, keindahan membutuhkan kesempurnaan dan keutuhan. Dalam hal ini, indah berarti utuh dan sempurna, serta tidak memiliki kekurangan apa-apa dalam keberadaannya. Sebaliknya, buruk berarti ada sesuatu yang tidak ada pada bagian tertentu yang sesungguhnya diperlukan agar bentuknya menjadi sempurna atau tidak berhasil berperan dengan sempurna. Keburukan terjadi karena ketidakhadiran cahaya, tatanan, atau keutuhan yang seharusnya ada tetapi tidak ada.

Segala sesuatu yang kita temukan telah memanggil kita untuk mengatasi diri mereka sendiri menuju kebaikan dan keindahan yang abadi. ${ }^{38}$ Berdasarkan kemampuan mereka sendiri, mereka tidak mampu memuaskan kita dengan sempurna karena setiap ciptaan itu terbatas, tidak utuh, dan berubah-ubah. Oleh karenanya, kita merindukan sebuah keindahan yang penuh, sempurna, dan abadi yaitu Allah atau hakikat keindahan. Berbagai perumpamaan Kitab Suci menyatakan bagaimana keindahan yang sejati telah mengubah atau memperindah umat manusia. Mendengar Sabda Allah berarti kita menghargai, menaati, dan sesuai dengan rahmat dan panggilan dari hakikat keindahan. Sabda ini diharapkan menjadi gema yang hidup dalam diri mereka yang mendengarnya. Kegembiraan dari mereka yang mempunyai telinga untuk mendengar Sabda Allah dihubungkan dengan kegembiraan dari mereka yang mempunyai mata untuk melihat keindahan kebaikan dan maknanya yang benar di dalam Yesus Kristus. ${ }^{39}$ Sebagai Penyelamat, Yesus membebaskan kita dari berbagai rintangan pendengaran, penglihatan, dan kegembiraan dalam mencintai Pencipta, Penopang, dan Pemenuh dunia ini selaku Bapa. Bahkan melalui karunia Roh, kita dimungkinkan untuk mengenal tatanan alam semesta yang teratur di dalamnya. Dengan kata lain, Allah sebagai hakikat keindahan telah memperindah dunia melalui sabda-Nya yang berbicara dan terangNya yang memancar di tubuh Kristus dan bait Roh Kudus. Karena diterangi sabda dan dicintai oleh Roh, semua ciptaan dapat menyinarkan keelokan sejati dari Allah Tritunggal selaku hakikat keindahan itu.

Berbicara hakikat keindahan, Allah mengajarkan perintah agung yang menunjuk mencintai Allah di atas segalanya dan sesama seperti diri kita sendiri telah mengungkapkan rahmat dan panggilan Allah demi keindahan umat manusia dalam mewujudkan secara penuh persaudaraan ilahi dan manusiawi. ${ }^{40}$ Keindahan yang abadi telah memberikan suatu tatanan yang baik dan indah kepada semua ciptaan. Keindahan tatanan yang diciptakan dimungkinkan membuat segala sesuatu terarah kepada Allah dengan saling membantu. Hal ini didukung adanya kesadaran manusia bahwa ia terbatas dan diajak untuk saling membantu sehingga tidak seorang pun sanggup mencukupi keperluannya sendiri untuk mencapai kesempurnaan atau kebahagiaan dirinya. Dengan demikian, keindahan yang abadi menghendaki untuk membuat segala sesuatu menjadi indah.

\footnotetext{
${ }^{37}$ John Navone. Toward A Theology of Beauty, hlm. 83.

${ }^{38}$ John Navone. Toward A Theology of Beauty, hlm. 86.

${ }^{39}$ John Navone. Toward A Theology of Beauty, hlm. 87.

${ }^{40}$ John Navone. Toward A Theology of Beauty, hlm. 88.
} 


\section{Pengalaman Orang Kristen tentang Keindahan Allah dalam Teologi Keindahan}

Navone menjelaskan pengalaman orang Kristen tentang keindahan merupakan sebuah pengalaman iman dan memiliki pengandaian sendiri. ${ }^{41}$ Pengandaian di sini menunjuk pada Allah memberikan diri-Nya sendiri kepada kita dalam semua pengalaman kita di mana Allah tidak hanya menciptakan, tetapi mendukung dan memanggil semua ciptaan menuju kesempurnaan. Selain itu, berpijak pada prinsip iman orang Kristen ketika menafsirkan seluruh pengalamannya, Allah merupakan hakikat kebaikan, kebenaran, dan keindahan. Ignatius dari Loyola melihat hakikat cinta dan kebaikan yang melayani kita melalui semua ciptaan dengan prinsip iman dari penafsiran orang Kristen yang memampukan Paulus melihat bahwa Allah turut bekerja dalam segala sesuatu untuk mendatangkan kebaikan bagi mereka yang mengasihi Dia yaitu bagi mereka yang terpanggil sesuai dengan rencana Allah (Roma 8:28). ${ }^{42}$ Dalam hal ini, Paulus dan Ignatius menegaskan bahwa kebaikan, kebenaran, dan keindahan telah bekerja untuk kebaikan kita.

Berbicara pengalaman orang Kristen dalam konteks teologi keindahan, pandangan teologis Bernard Lonergan dan Simon Tugwell dapat membantu kita menjernihkannya. Lonergan menawarkan pemikiran tentang pertobatan religius maupun orang Kristen yang mengandung pengalaman religius. ${ }^{43}$ Pertobatan religius merupakan ruang orang sedang jatuh cinta, menyerahkan diri secara utuh dan tetap tanpa syarat-syarat, pembatasan, dan tidak tanggung-tanggung bukan sebagai suatu tindakan, melainkan keadaan dinamis yang mendahului dan menjadi dasar berbagai tindakan selanjutnya. Pertobatan religius diharapkan dapat mengubah subyek manusiawi ke suatu subyek yang menyayangi, menarik, menangkap, meresapi, dan memiliki melalui suatu cinta yang utuh dan dari dunia lain. Bagi orang Kristen, hal itu merupakan cinta Allah yang mengaliri hati kita melalui Roh Kudus yang telah diberikan kepada kita. Prinsip komunitas Kristen yaitu mempersatukan karunia batin dari cinta Allah pada jantung pertobatan religius dengan perwujudan keluarnya dalam diri Yesus Kristus dan dalam diri mereka yang mengikuti-Nya.

Berbicara tentang keindahan, Lonergan menegaskan pertobatan religius mengandung dasar dan pusatnya pada misteri yang mempesona tetapi sekaligus menakutkan (mysterium fascinans et tremendum) yang juga ada dalam agama dunia, di antaranya Kristianitas, Yudaisme, Islam, Mazdaisme, Zoroastrian, Hinduisme, Budhisme, dan Taoisme. ${ }^{44}$ Pada proses pemikirannya, Lonergan mencatat bahwa penggambaran Friedrich Heller tentang wilayah umum yang dialami agama-agama tersebut mengandung unsur realitas transenden, imanen dalam hati manusia, keindahan, kebenaran, keadilan, kebaikan tertinggi, cinta, belas kasih, bela rasa. ${ }^{45}$ Realitas demikian diraih melalui pertobatan, penyangkalan diri, dan doa yang berpusat pada upaya mencintai Allah. Mencintai Allah berarti saya mengatasi diriku sekaligus saya menyangkal diriku supaya tertransendensi. Semua dilakukan dengan menaruh perhatian pada Tuhan yang terwujud dalam doa, meditasi, dan kontemplasi.

\footnotetext{
${ }^{41}$ John Navone. Toward A Theology of Beauty, hlm. 91.

${ }^{42}$ John Navone. Toward A Theology of Beauty, hlm. 91.

${ }^{43}$ Bernard Lonergan. Method in Theology. (London: Darton, Longman and Todd, 1972), hlm. 240-241.

${ }_{44}^{4}$ Bernard Lonergan. Method in Theology, hlm. 245.

45 John Navone. Toward A Theology of Beauty, hlm. 94.
} 
Orang Kristen percaya bahwa apa yang telah dilakukan oleh Allah dalam diri Yesus Kristus sesuai dengan kemungkinan bahwa Allah menyapa kita dalam dunia ini dengan cara tertentu yang dapat kita pahami. Allah mendekati kita secara pribadi dalam Yesus Kristus dan membangkitkan reaksi pribadi dari kita. Meski kita orang Kristen percaya bahwa Yesus bekerja dalam gereja dan dalam dunia-Nya (Matius 28:20), kita tahu bahwa Dia berada dalam diri kita dengan suatu cara yang misterius karena kita masih menantikan penampakan kemuliaan-Nya (Titus 2: 13). ${ }^{46}$ Pengenalan akan Allah lahir dari pengalaman konkrit. Berbagai macam pengalaman batin menjadi bagian pematangan spiritual atau religius kita. Roh Kudus memampukan kita untuk menanggapi rahmat dan panggilan Allah bersama dengan berbagai perasaan dan pengalaman yang bercampur baur. Pengalaman yang tidak dapat diperkirakan merupakan masukan yang berguna karena dalam dunia ini, kita tidak akan pernah melihat dan merasakan lebih daripada hanya gambaran tentang kepenuhan hidup yang tersembunyi yang kita miliki dalam Kristus. ${ }^{47}$

Simon Tugwell menegaskan bahwa pengalaman religius kita adalah ironis. ${ }^{48} \mathrm{Hal}$ ini berarti apa pun jenis pengalaman yang kita miliki, kita memilih dan memikirkan apa yang mungkin baik untuk menggambarkan segi tertentu dari realitas yang kita miliki secara tersembunyi di dalam Kristus, tetapi realitas itu tidak pernah dapat dikenali secara utuh. Semua jalan kehidupan merupakan bagian penyelenggaraan Allah yang mengatur alam semesta. Sekalipun dalam refleksi, kita menyadari bahwa kita telah berbuat salah, maka kita harus mengakui. Kesadaran bahwa kita telah berbuat salah merupakan bagian dari keseluruhan cara yang dipakai Allah untuk menuntun alam semesta ini menuju tujuan akhirnya. Kesalahan yang sering kita buat yaitu berpikir bahwa ada sesuatu yang secara khusus menuntun sekitar situasi-situasi yang disertai oleh perasaan-perasaan tertentu dari dalam diri kita. ${ }^{49}$ Bertumbuhnya kepekaan kita terhadap kehendak Allah seharusnya menghasilkan kesetiaan dan kepercayaan yang lebih besar pada kehendak Allah yaitu kita hidup berada dalam persahabatan dengan Allah.

Orang Kristen dimungkinkan mempunyai perasaan yang dininabobokkan oleh cinta Allah dengan mempertanyakan apakah hal ini merupakan imajinasi. Dasar pengalaman religius orang Kristen yaitu adanya kesadaran bahwa Allah mencintai kita. Navone mengatakan mungkin memang baik bahwa imajinasi dilibatkan dalam perasaan kita, tetapi kebenaran dari dasar pengalaman religius harus ditegakkan. ${ }^{50}$ Kesalahan terjadi ketika menyamakan cinta dengan perasaan sehingga menghentikan perasaan lalu dimengerti juga menghentikan cinta. Orang Kristen menyatakan kematangan iman ketika mereka menafsirkan pengalamannya dalam terang Yesus Kristus dan ajaran-Nya. Hal ini juga berlaku sebaliknya. Orang Kristen menjadi tidak matang ketika mereka mencari suatu pengalaman religius, khususnya yang secara tidak langsung berpijak pada pengandaian bahwa ajaran Kristus dan komunitas imanNya tidak memadai.

\footnotetext{
${ }^{46}$ John Navone. Toward A Theology of Beauty, hlm. 95.

${ }^{47}$ John Navone. Toward A Theology of Beauty, hlm. 96.

${ }^{48}$ John Navone. Toward A Theology of Beauty, hlm. 96.

49 John Navone. Toward A Theology of Beauty, hlm. 97.

${ }^{50}$ John Navone. Toward A Theology of Beauty, hlm. 98.
} 
Bila kita merasa bahwa hidup kita miskin dalam hal pengalaman religius, hal itu tidak berarti disebabkan oleh kurangnya pengalaman religius khusus tertentu, melainkan karena kita tidak menempatkan pengalaman keseharian kita dalam konteks keyakinan iman. Allah memberikan diri-Nya sendiri dalam seluruh pengalaman kita sehingga setiap hal yang sangat biasa pun dapat menjadi luar biasa. Tidak ada satu pun kenyataan yang demikian pahit karena semua kenyataan bermakna. Hal ini juga berlaku bahwa tidak ada satu pun pengalaman manusia yang tidak dapat diberi makna karena semua pengalaman manusia bermakna. Setiap pribadi mengejawantahkan penafsiran dari Allah, dunia, sesama, dan dirinya sendiri yang dicapai dalam pengalaman konkrit, dan pada gilirannya diungkapkan pada tingkat mengadanya dan menjadinya seseorang. Dalam hal ini, Navone menjelaskan bahwa cerita hidup manusia memiliki penafsirannya sendiri karena cerita merupakan hasil dari pemahaman dan penafsiran yang dimiliki oleh orang tertentu berkenaan diri mereka sendiri, situasi, peran, dan keadaan mereka. ${ }^{51}$

Berbagai prinsip orang Kristen untuk menafsirkan pengalaman manusia merupakan bagian prinsip iman dari tradisi suci melalui proses penerimaan dan penerusan. Identitas perwahyuan yang ditanamkan oleh Allah kepada manusia harus dipelihara dan dilestarikan pada generasi ke generasi. Dalam prosesnya, pendengaran dan iman orang lain tidak diarahkan oleh penerima dan saksi mata perwahyuan asli, tetapi terutama diarahkan oleh Tuhan yang telah berbicara kepada mereka di masa lampau (Ibrani 1: 1-2). Setiap pergantian generasi yang mewakili penyatuan mata rantai tradisi suci masa lampau mempunyai tanggung jawab untuk mendengar dan memahami atau menafsirkan pesan asli atau penyingkapan atau penafsiran iman sejati tanpa menghilangkan atau menambahkan sesuatu yang dapat jadi justru mengganggu maknanya. Oleh karenanya, mereka yang lahir sesudah peristiwa pewahyuan harus melihat ke masa lampau untuk menemukan pesan atau prinsip penafsiran iman yang telah mendahului eksistensi mereka.

Dalam teologi keindahan, pengalaman orang Kristen dapat mengantarkan kita pada jalan memandang Allah. Segala sesuatu telah ditentukan dari awal yang dirancang untuk membuat kita dapat mencintai dan menghargainya, termasuk pribadi yang dihadirkan dalam konteks sejarah hidup kita. Navone menegaskan keadaan yang sesungguhnya dari gambaran kita tentang Allah, keaslian pengetahuan kita tentang Allah, kematangan cinta akan Allah, dan jalan yang membuat kita memahami atau membayangkan Allah akan selalu bergantung pada keadaan yang sesungguhnya dari gambaran kita tentang realitas-realitas yang dapat diraba atau disentuh. ${ }^{52}$ Semua hal tersebut bergantung pada kematangan yang dengannya kita mencintai segala sesuatu dan pribadi yang terbatas secara bertanggungjawab bergantung pada keadaan yang sesungguhnya dari gambaran kita tentang realitas-realitas yang dapat diraba atau disentuh.

Pengalaman orang Kristen tentang keindahan Allah dalam segala sesuatu dan pribadipribadi lahir dari cinta, ketulusan cinta, dan ketulusan yang membuat kita berelasi dengan pribadi-pribadi dan segala sesuatu yang dihadirkan pada kita dalam konteks sejarah hidup

\footnotetext{
${ }^{51}$ John Navone. Toward A Theology of Beauty, hlm. 100.

52 John Navone. Toward A Theology of Beauty, hlm. 103.
} 
kita. ${ }^{53}$ Peziarahan jiwa menuju hakikat keindahan selalu menjadi jalan melalui akal budi. Dengan gigih, Ewert H. Cousins menentang praanggapan yang menyebar luas bahwa spiritualitas berhubungan dengan afektivitas secara eksklusif. ${ }^{54}$ Pengajaran gereja memberi pencerahan pada perjalanan komunitas orang Kristen menuju hakikat keindahan. Pengajaran ini membantu kita untuk hidup dalam misteri Allah yang kudus dan mencintai secara abadi. Pengajaran gereja mengantar kita kepada perjumpaan dengan Kristus, pertobatan hati, dan pengalaman akan Roh Kudus dalam komunitas iman.

Teologi keindahan menawarkan pengalaman orang Kristen terjadi dalam waktu dan ruang, dan berdasarkan pada pewahyuan historis Yesus Kristus dan komunitas iman-Nya. ${ }^{55}$ Pengalaman orang Kristen mencakup penafsiran iman dari masa lampau, sekarang, dan mendatang. Pengalaman ini diisi mengenang dan merefleksikan apa yang dilakukan Allah dalam Yesus Kristus sebagai pemenuhan janji Allah kepada Abraham, sembari menantikan kedatangan kedua dari Tuhan. Hal itu merupakan pengalaman waktu sebagai kairos, di mana Allah dialami hadir dan aktif, sebagai lawan dari waktu sebagai chronos, di mana waktu yang dialami sebagai rutinitas atau pengulangan yang terpisah dari Allah.

Sebagai suatu pengalaman yang meliputi segala sesuatu yang berakar dalam iman, pengharapan, dan kasih abadi, pengalaman orang Kristen menjadi suatu keprihatinan dari semua realitas yang memiliki aspek relatif sama seperti memiliki aspek absolut. ${ }^{56}$ Pengalaman tersebut menempatkan seluruh ralitas yang dialami dalam terang dan bayangan realitas transenden. Dengan terang iman, harapan, dan kasih Kristen keindahaan sejati, semua realitas tercipta menjadi terserap dalam semua kebaikan yang dilingkupi Allah. Iman yang membuat kita memahami kesemarakan atau keindahan cinta dan kebijaksanaan yang transenden.

\section{Kesimpulan}

Dalam menguraikan gagasan Allah melalui teologi keindahan, artikel ini dapat disimpulkan melalui pengandaian jika Allah adalah hakikat kebahagiaan, persekutuan dengan Allah menjadi persekutuan dengan hakikat kebahagiaan. Jika hakikat kebahagiaan selalu mengetahui kebenaran-Nya dan mencintai kebaikan-Nya, serta berkenan pada keindahanNya, kebahagiaan akhir dan abadi kita ditinjau dari segi karunia penglihatan yang membahagiakan merupakan persekutuan dengan hakikat kebahagiaan, yakni mengetahui kebenaran-Nya, mencintai kebaikan-Nya, dan berkenan pada keindahan-Nya.

\section{Referensi}

Balthasar, Hans Urs von. The Glory of the Lord: A Theological Aesthetics III: Studies in Theological Styles. San Francisco: Ignatius, 1982.

Barth, Karl. Church Dogmatics. Edinburgh: T \& T Clark, 1970.

Begbie, Jeremy. Beholding the Glory: Incarnation through the Arts. Grand Rapids: Baker, 2000.

Cousins, Ewert H. Bonaventure: The Soul's Journey into God. New York: Paulist Press, 1978.

\footnotetext{
${ }^{53}$ John Navone. Toward A Theology of Beauty, hlm. 104.

${ }^{54}$ Ewert H. Cousins. Bonaventure: The Soul's Journey into God. (New York: Paulist Press, 1978), hlm. 59.

${ }^{55}$ John Navone. Toward A Theology of Beauty, hlm. 108.

${ }^{56}$ John Navone. Toward A Theology of Beauty, hlm. 110.
} 
Dyrness, William A. Visual Faith: Art, Theology, and Worship in Dialogue. Grand Rapids: Baker Academic, 2001.

Hart, David Bentley. The Beauty of the Infinite: The Aesthetics of Christian Truth. Grand Rapids: Eerdmans, 2003.

Lonergan, Bernard. Method in Theology. London: Darton, Longman and Todd, 1972.

Navone, John. Toward A Theology of Beauty terj. Willem Daia. Yogyakarta: Kanisius, 2007. Ryken, Philip Graham. Art for God's Sake: A Call to Recover the Arts. New Jearsey: P \& R Publishing, 2006.

Schaeffer, Francis A. Art and The Bible. Downer Grove: InterVarsity Press, 1973.

Taylor, W. David O. For the Beauty of the Church: Casting A Vision for the Arts. Grand Rapids: Baker Books, 2010.

Turner, Steve. Imagine: A Vision for Christians in the Arts. Downer Grove: InterVarsity Press, 2001 